\title{
The Influence of Foreign Direct Investment on Accommodation Patterns in Vietnam as a Result of the Open Door Policy
}

\begin{abstract}
Before the “open door” policy doi moi, the Vietnamese government had monopolised all sectors of tourism in the country. In 1987, one year after the beginning of doi moi, the state issued the Law on Foreign Investment, which encouraged foreign direct investment (FDI) in Vietnam, especially in the tourism industry. This paper examines the influence of the resulting influx of foreign direct investment on tourism accommodation patterns in Vietnam. A synopsis of policy and background of FDI in Vietnam accommodation is followed by an examination of developments, projects and experiences in this field since doi moi. The paper then investigates the effects of FDI in Vietnam tourism accommodation on developments and practices in Vietnam's accommodation market, including the traditional state-owned accommodation subsector. The paper integrates insights gained from interviews with operators of joint-venture and state-owned hotels in Vietnam.
\end{abstract}

Keywords: foreign direct investment, doi moi, tourism accommodation, tourism management, Vietnam. 


\section{Vietnam's Open Door Policy}

\section{Doi Moi}

In 1986, the Congress of Vietnam introduced an economic programme called doi moi (Renovation), which has been compared to Gorbachev's contemporaneous glasnost campaign in the Soviet Union. The Vietnamese Communist Party’s new policy called for measures including the decentralisation of the planning system, a decrease in the number of government ministries and bureaucracies, reliance on the private sector as an engine of economic growth, and allowing state and privately-owned industries to trade directly in foreign and international markets. Doi moi has succeeded remarkably in moving the country from a stagnant, centrally planned Sovietstyle economy with macroeconomic instability to a socialist-oriented mixed market-oriented economy characterised by rapid growth (Kokko, 1998: 2). Developments such as the end of the US trade embargo on Vietnam in 1994, Vietnam's 1995 entry into ASEAN, and Vietnam's admission to the WTO in 2007 indicate an increasing re-integration of Vietnam into international markets.

\section{Doi Moi and Tourism}

With these political and economic shifts, Vietnam has become a much more accessible and attractive destination in the international tourism market and has been rediscovered by tourists from around the world. Consequently, Vietnam's tourism industry has experienced a period of 
meteoric growth in recent years. Over 4.1 million international tourists arrived in Vietnam in 2007, an increase of over ten-fold since 1990 (www.vietnamtourism.com/e_pages/news/ index.asp?loai=2\&uid=6751). Tourism accommodation and travel agencies in Vietnam earned a total of 10,743.5 billion dong (USD 670 million) in 2004, compared to 4,458.5 billion dong (USD 280 million) in 2000 (www.gso.gov.vn). It has been predicted that earnings from foreign visitors to Vietnam in 2010 will reach USD 11.8 billion (Sadi and Henderson, 2001: 70). As of 2006, an estimated 234,000 people worked in Vietnam's tourism sector, with another 510,000 jobs in related industries (John, 2006). Aside from this quantifiable growth, tourism in Vietnam has also changed in character during the years since 1986. Vietnam's tourism industry is experiencing the emergence of new tourism niches, new kinds of attractions and businesses, new breeds of tourists and unfamiliar types of tourism such as eco-tourism and war tourism. Far from being merely a side-effect of economic and political changes in Vietnam, growth and change in the tourism sector has also generated effects that have an influence on politics, economics and Vietnamese society in general.

The current Socio-Economic Strategy of Vietnam for the years 2001-2010 continues the doi moi programme and sets out goals for the further improvement of the country in all its facets. This paper discusses the development of foreign direct investment in the accommodation sector in the context of doi moi as an ongoing process. It contains insights gained through interviews with various figures of responsibility in government and the tourism industry, both public and private, who have experienced the development of FDI in within Vietnam's evolving transition economy. 


\section{Methodology}

\section{Challenges and Limitations}

Research in Vietnam is still associated with certain problems, and there is relatively little published research on tourism in Vietnam. The English language literature on this subject is very limited. The authors also found that most government organisations are either not willing to share information and documents, or that the statistics in question do not exist or were never recorded (Henderson, 2000; Lloyd et al, 2004).

Many researchers and scholars have referred to this lack of reliable and accurate basic statistical information data for Vietnam, and in addition, the country lacks continuous historical data on the development of tourism (Lloyd, 2004; Lloyd et al, 2004; Mok and Lam, 1998; EIU, 1993; Henderson, 2000; Theuns, 1997). Insufficient standardisation or coordination of measuring periods and time spans from province to province or from year to year, inadequate training, resources and interdepartmental coordination are all likely contribute to this problem, as does increasing forgery, smuggling and falsification of documents to meet a growing demand by researchers and organisations for data that may not exist in the form required (Lloyd et al, 2004). It has been said that the open door policy has seemingly brought Vietnam's communist government to realise the need to improve the reliability and availability of data in order to attract potential foreign investors who need trustworthy and consistent statistics as a basis for their development strategies (EIU, 1993; Mok and Lam, 1998). The Statistical Office in Ho Chi Minh City plans to undertake a greater number of surveys and research in tourism and publish a 
greater variety of tourism statistics in their yearbooks (Interview with Director of Statistics Office, Ho Chi Minh City).

This study investigates changes in tourism that occurred during the first years of the twenty first century. However, some of the data referenced in this paper comes from the period between the beginning of doi moi and the turn of the century, in order to provide a context for the developments that led in to this situation. Political and financial events of recent years make it difficult to extrapolate the trends identified in this paper into subsequent years or the future.

\section{Choice of Methods}

The use of key interviews was chosen as the principal method of gathering data for this paper, and the research combines a series of interviews conducted by the lead author with administrative figures in two international hotel chains, seven state owned hotels and three guesthouses at different locations in Vietnam. These were supplemented with interviews with a senior expert in hotels from the Vietnam National Administration of Tourism (VNAT) and a senior official of the Foreign Investment Agency, Ministry of Planning and Investment (MPI). Desk research from secondary sources including government documents, newspapers and periodicals supplemented the information gathered from the interviews.

Firms, organisations and individuals that have been active in Vietnam tourism from before doi moi were primarily sought out for interviews, in order to get insight into patterns over a longer period of time, even before the beginning of doi moi. Because of the government monopoly on 
tourism businesses before 1986, state-owned hotels and firms in Vietnam tended to be the longest-established and thus were specially targeted for interviews. Interviewees were also chosen from foreign firms, FDI (Foreign Direct Investment) and other private enterprises that have been operating in Vietnam since at least the beginning of the development of private and FDI enterprises in Vietnam tourism as part of doi moi. To gain an understanding of tourism policy changes from the vantage point of the makers and enforcers of this policy, interviews were also conducted with representatives of government bodies.

A semi-structured interview form was used, involving the implementation of a number of predetermined questions and/or special topics, asked of each interviewee in a consistent and systematic order, but allowing the interviewer sufficient freedom to digress in order to probe beyond the immediate answers to the predetermined questions. New issues often arose during an interview, which led the interviewer to ask additional questions to probe a certain direction. Such questions varied among interviewees. One examples of this is a line of questioning regarding hotel room prices that revealed patterns in changes of accommodation development, supply and demand since the beginning of doi moi.

Multiple lines of questioning of different interviewees at different levels or sectors were used to validate and cross-check interview results, such as the interviewing of private, state-owned and international operators as well as representatives of the VNAT regarding the development of the accommodation sector. Representatives of government bodies were often in a position to verify the results of interviews with representatives of tourism businesses and data from other primary sources. 


\section{Contribution}

A 2004 survey of representatives of the investment promotion agencies of more than 50 nations (most of them developing countries) determined that tourism is one of the main industries being targeted by these countries for FDI (Endo, 2006: 601). While dealing specifically with Vietnam, this paper contributes to knowledge on investment in the developing world in general, and socialist countries in particular. It offers specific insights into the ways in which the introduction of aspects of a free market economy into a socialist system affects the risks and opportunities for investment. Through the use of elite interviews, the research gives an understanding of how such a broad macro-economic transition affects, and is affected by, individual tourism operators. It goes beyond the discussion of the purely economic and political aspects of the investment climate within political transition to reveal the workings of mechanisms of knowledge transfer and cultural negotiation between public and private, domestic and foreign, established and startup interests in this context.

\section{FDI/Joint Ventures in Vietnam}

\section{Legal Framework}

In 1987, a new foreign investment law was inaugurated, encouraging foreign investment by offering enticing conditions for joint enterprises and foreign-owned corporations. The Law on Foreign Investment opened the Vietnamese market to investment by foreign firms and persons and guaranteed them rights of ownership and fair treatment including freedom from 
expropriation and nationalization of assets. In order to encourage opportunities for transfer of capital and expertise, the law favours joint ventures over the other models of foreign investment (Ngo Ba Thanh, 1993: 95). The duration of foreign investment in a project was originally limited to 20 years.

A June 30, 1990 amendment to the 1987 Law made it possible for private joint-stock limited liability organizations to enter into joint ventures with foreign firms for the first time. This provision was extended by a second amendment on December 23, 1992 to include private companies. This same amendment also extended the maximum allowable duration of operation of foreign-funded firms in Vietnam to 70 years. Vietnamese partners are allowed to contribute only 25 to 30 per cent of the capital for such projects, with a provision for a gradual increase in capital share over time (Le Van Sang, 1995: 121). Other amendments followed in 1996, 2000 and 2003. According to a Senior Official of the Foreign Investment Agency (FIA) of the Ministry of Planning and Investment (MPI), in 1996 the Foreign Investment Agency carried out its first study and SWOT analysis comparing Vietnam's investment law to other countries in an effort to learn how Vietnam could attract more FDI. Before this, no need was seen for surveys or research.

Foreign investment is allowed in all economic sectors but specifically encouraged in several specific niches, among them 'foreign exchange earning services' such as ship repair, air- and seaport services and tourism (Theuns, 1997: 312). In the original version of the Law, foreign firms were to be liable to pay tax on their profits at a rate of between five and ten per cent, though tax exemption could be granted in special cases to encourage investment (Law on 
Foreign Investment, 1987: Article 33). The only areas from which foreign investment was explicitly excluded by the Law on Foreign Investment were those related to national security (Wayne and Lejeune, 1996: 203).

\section{Early Development of FDI}

In the period 1987 to 1995, foreign investment in Vietnam totaled USD 20.63 billion. By 1996, FDI in Vietnam was the second highest of any country in the world, as a percentage of GDP (Freeman, 2002: 5). According to Vasavakul, in the mid 1990s tourism was the most popular sector for foreign investment, accounting for over USD 3.3 billion. (1997: 348). Investors from 64 nations, invested in Vietnam up to the end of 2003. Most foreign investment came from Asian countries (Leproux and Brooks, 2004: 2).

However, in 1996, FDI declined for the first time since doi moi was adopted, and economic growth dropped to 4 per cent. Analysts have commented that some aspects of the Renovation Program are nothing more than empty rhetoric on the part of the government, and foreign investors may have come to the realization that the country's political climate may not have been as open as was originally assumed as shown, by the 1996 campaign to abolish 'social evils' which called for the prohibition of signs in foreign languages (Batha, 2000). Many internal factors may also have contributed to Vietnam's economic downturn, such as an excess of bureaucracy, which discouraged investment, a complicated and opaque system of rules and regulations, widespread corruption in the government and banking systems and favouritism for thousands of dysfunctional State-Owned Enterprises (SOEs) (Thayer, 2000). The downturn in 
FDI was exacerbated by the Asian financial crisis of 1997. The most fundamental obstacle for foreign investors was the Hanoi government itself (Hines, 2000), which had introduced doi moi in 1986 "not out of altruism, but because its hand was forced" (Mitton, 1998). The VCP has been accused of having taken two steps forward and one step back (ibid).

\section{Encouraging FDI}

In order to encourage investors from countries from outside the region, in 1998 the Agency carried out a promotion campaign in European countries for investment in Vietnam (Interview, A, 2004). A 1999 ruling allowed foreign investors to own a stake of up to 30 per cent in socalled 'equitized' state-owned enterprises in several sectors, including hotels (The Saigon Times Daily, 1999). In 2005, there was more than USD 2 billion of foreign direct investment in Vietnam, or 4 per cent of Vietnam’s GDP (ADB, 2006: 8).

Encouraging FDI is a central concern behind market-oriented policy reforms in Vietnam. FDI is seen as a catalyst for economic transition and revitalization of the private economic sector (ADB, 2006: 10). Yasheng (2001, cited in Freeman, 2002: 8) pointed out that FDI has served as a sort of “ersatz private sector" in China, which, like Vietnam, has a transitional economy, associated with a low-level of domestic private economic development and a sluggish public sector. Vietnam's bountiful natural resources and low labor rates, as well as the relatively high education level and pronounced work ethic of the Vietnamese people, contribute to the attractiveness of the country for foreign investors (Freeman, 2002: 4). However, encouraging foreign investment in Vietnam proved difficult because of a lack of technological capability and 
managerial experience in the country. The infrastructure, destroyed during the War, was in a sorry state. The press criticized the administration for having difficulty in abandoning the 'guerrilla mentality' and making the transition from a wartime to a peacetime society (Duiker, 1995: 145). Growth in the private sector and foreign direct investment (FDI) were concentrated mainly in the South, where better infrastructure, longer personal and business relations with Vietnamese and Chinese abroad, and a supportive local administration created a more favorable environment than in the North (Dodsworth, et al, 1996: 16). Despite improvements in its investment climate, Vietnam remains less investor-friendly than other countries in Southeast Asia, and Vietnam is still not regarded as an economically progressive environment. In 1995, the country ranked $98^{\text {th }}$ out of 100 rated nations in terms of economic freedom. By 2005, it had only progressed to $142^{\text {nd }}$ out of 157 . FDI in Vietnam also still tends to concentrate on the principal cities, in part because transport, infrastructure and administrative services are much less developed in the rest of the country (ADB, 2006: 34, 46). For example, between 1988 and 2003, 19 per cent of FDI in Vietnam was in Hanoi and 26 per cent in Ho Chi Minh City (Leproux and Brooks, 2004: 2). Vietnam's great success in attracting FDI in spite of these hindrances attests to the high prospective gains to be made in the country or the value of establishing oneself early within an emerging market, for which firms are apparently currently willing to accept a high level of risk and constraints, at least for the present.

\section{Contribution of FDI}

Retrospective assessments of the significance of the contribution of FDI to the Vietnamese economy vary, according to which indicator is cited. At the end of the 1990s, foreign direct 
investment companies accounted for 13 per cent of Vietnam's GDP, 27 per cent of its non-oil exports, 35 per cent of industrial production and one-quarter of tax revenues. In the year 2000, the total revenues from FDI in Vietnam were USD 6.5 billion and tax income from FDIs was USD 280 million (Freeman, 2002: 3). However, the FDI sector accounted for only a small proportion of total employment in the country: 2 per cent in 2000 and 0.6 per cent overall between 1991 and 2000 (Leproux and Brooks, 2004: 12). In 2001, the World Bank estimated that average total investment in Vietnam would have to attain a level of 30 percent of the GDP by 2010 (5 percent higher than in the 1990s). A government reform program aims at reducing state sector investment to encourage investment from the private sector (Tenev, et al., 2003: 1-2). Preliminary figures from the General Statistics Office of Vietnam for 2007 show that foreign direct investment capital accounts for about 129 trillion dong, or about 24.8 percent of total investment capital in the country. This is an increase of 193 percent from the 2006 FDI amount (http://www.gso.gov.vn/default_en.aspx?tabid=471\&idmid=3).

The Foreign Investment Law allows for foreign investment in Vietnam in the form of a business corporate contract (BCC), a joint venture or fully foreign-invested properties. In 1998, it was noted that most foreign investors still preferred to have Vietnamese partners who are familiar with the Vietnamese way of doing things ( $\mathrm{Li}$, et al, 1998). However, six years later, foreign investors had gained enough experience in Vietnam to feel confident enough to avoid the complications of domestic partners by increasingly deciding for 100 per cent ownership of their projects.

\section{FDI in tourism in Vietnam}


Twenty per cent of the USD 30 billion of FDI pledged to Vietnam between 1988 and 1997 was designated for tourism (Sadi and Henderson, 2001: 71). FDI in tourism in Vietnam grew from USD 7.4 million (2 per cent of total FDI) in 1988 to USD 1.9 billion (30.7 per cent of total FDI) in 1995, increasing by around 100 per cent yearly. The number of projects remained more or less constant, but the average size of projects undertaken grew steadily from year to year, from USD 1.4 million in 1988 to USD 66.7 million in 1995. An increase in the average duration of tourism FDI projects from 9 years to 27 years over the same period reflects the growth in the size of projects undertaken and also indicates an increase in investor confidence in the Vietnam tourism market. Accounting for USD 1.3 billion in funds, Taiwan was by far the largest source of the investment in Vietnamese tourism in the eight years from 1988 to 1995 (Erramilli, et al, 1997: 277-278).

The decline in FDI in Vietnam from 1996 has been especially pronounced in the hospitality and tourism sectors, where slow return on investment, complicated procedures and the communist government's "culture of secrecy" have served to disillusion many foreign investors (Sadi and Henderson, 2001: 78-80). To this day, a number of barriers and pitfalls for foreign direct investment still exist in Vietnam. Besides the general hurdles to FDI already discussed in this paper, tourism projects are especially dependent on infrastructure, and tend to suffer from lagging infrastructure improvements, such as the promised but not-yet-built international airport on Phu Quoc Island, on which the future tourism development potential of the island will rely. The lack of trustworthy market figures for Vietnam and continuing prevalence of opaque, inefficient and corrupt bureaucracy are further complications and sources of discouragement (Sadi and Henderson, 2001: 78-80). 
Some FDI-invested sites, such as Phu Quoc Island, which developers plan to turn into a worldclass ecotourism destination, are eligible to apply for the highest preferential policies allowed by the Vietnamese government (http://investphuquoc.com/investment.html) including expediting license procedures and establishing a Phu Quoc Investment and Development Management Board to assist investors (http://english.vietnamnet.vn/biz/2008/08/800352/). Some of the twenty-one projects on the island with a total revenue of USD 1.72 billion are already contributing to a 16 percent annual economic growth rate on the island for the past three years (http://www.vietnamtourism.gov.vn).

\section{FDI / Joint Ventures in the Tourism Accommodation Sector}

\section{Overview}

Hoping to encourage tourism to the country, the Vietnamese government declared 1990 "Visit Vietnam Year”. This ambitious program is considered by the Economist Intelligence Unit (EIU) (1993) to have failed due to a shortage of hotel rooms, among other factors. Some hotels remaining from the French colonial era had been transformed to different uses or allowed to fall into disrepair, and the standard of Vietnam's accommodation provisions was seen as inadequate for the international tourists who began to return after 1986, due to the lack of integrated entertainment and recreation facilities to supplement room and board (VNAT/UNDP/WTO, 1991: 22). Thus, at the beginning of the 1990s, accommodation of international standard in Vietnam was very limited (VNAT/UNDP/WTO, 2001: 39). The EIU reported that in 1989 there 
were 18,877 rooms in accommodation units in Vietnam (1993: 69), but a UNDP and WTO document identified only 1,565 rooms that met international standards in 1990 (VNAT/UNDP/WTO, 1991: 20). These figures are indicative and not absolute, as the accuracy and reliability of data on tourism in Vietnam is notoriously weak (EIU, 1993; Theuns, 1997; Biles, et al, 1999;Travel Business Analyst, 1992: 21; VNAT/UNDP/WTO, 2001: 44).

Until doi moi, the Vietnamese government was the only provider of tourist accommodation in the country, but now state enterprises no longer hold a monopoly and private and foreign investors have also become involved. As a result of the shortfalls mentioned above, the Vietnamese government became more aware of the importance of tourism infrastructure and sought to spur development by prioritizing joint venture investment in tourism (EIU, 1993: 63). Since the Vietnamese government and domestic sector lacked the knowledge and financial means to develop a progressive hospitality sector unassisted, the State Committee for Cooperation and Investment (SCCI) looked favorably on granting approval to foreign investment proposals for hotel development (ibid). A senior official of FIA stated that large foreign hotel chains also attracted their own loyal customers to Vietnam, bringing foreign exchange income into the country (Interview A, 2004). Priority was put on refurbishing existing hotels to raise their standards. Hotel renovations were among the largest joint venture projects in terms of funds invested (Theuns, 1997: 314).

Hotel development accounted for most of the tourism FDI in the early to mid 1990s, ranging from 57.5 per cent to 99.4 per cent of the yearly total (Erramilli, et al, 1997: 280). Hotel development was one of three major investment areas that together made up 83 per cent of total 
foreign investment in 1992 (the other two were industry and oil/gas) (EIU, 1993: 63). By 2004, 239 FDI tourism projects had been registered in Vietnam, with total capital of USD 6.1 billion (Vietnam New Agency, 2004).

Pioneering FDI / Joint Venture Projects in Vietnam

For as long as FDI has been permitted in the Vietnamese accommodation sector, joint-venture hotels have played a driving role in raising the standards, scale and prices in Vietnam's hospitality industry in general. The following examples illustrate the type of enterprise that has been developed under these arrangements.

Constructed in Singapore in 1987 and originally sited at Australia’s Great Barrier Reef (World Maritime News, 11 April, 1997), the 200-room Saigon Floating Hotel was towed to Ho Chi Minh City and opened in December 1989 by Southern Pacific Hotels as a joint venture between Australian and Filipino interests and the Vietnamese Overseas Finance and Trade Corporation (OCFC) (Abbott and Abbott, 1996: 193; Travel Business Analyst, 1992: 19), becoming the only five-star international standard hotel in the city. Many of the hotel's facilities and features, such as international direct dial phone lines, international booking, a business centre and credit card facilities, were unique in Ho Chi Minh City at that time. By 1990, three-quarters of the hotel's rooms were rented by foreigners on a long-stay basis (Saigon Tourist and Saigon Tourist Association, 1990: 31, EIU, 1993: 68). The OCFC functioned as the 'facilitator' to help the project over bureaucratic hurdles and received full power of attorney for the project plus an annual fee of USD 750,000 and 15 per cent of profits (Travel Business Analyst, 1992: 20). The waterborne structure evaded the ban on foreign ownership of land and became an instant 
sensation in the city, although Vietnamese were not allowed to enter. When it first opened, people set up seats on the bank and charged VND 500 per half-hour for a place to sit and watch the hotel (Biles, et al, 1999: 224). The Floating Hotel ceased operating in August 1996 and was towed to a dry dock in Singapore (http://www.kurtwalter.net/the-saigon-floating-hotel.htm). It was subsequently bought by the Hyundai corporation and is now located in North Korea.

The joint venture Century Saigon Hotel opened on July 29, 1992 and had a 75 per cent occupancy rate in its first six months. The hotel's initial average room rate (ARR) was USD 108, comparable to the Floating Hotel's concurrent ARR of USD 110. In comparison, the Rex Hotel charged USD 60 per night, the Continental USD 85, the Saigon Star USD 78, the Norfolk USD 75 and the Chains First Hotel USD 43. Century International Hotels targeted an ARR of USD 123 for 1993 and USD 138 for 1994 (Militante, 1993). The lack of four and five-star accommodation in Vietnam in the early 1990s allowed hotels in this class to charge room rates of around USD 150 by 1993 (Michael, 1993).

The New World Saigon Hotel, constructed as a joint venture between a state-owned enterprise and a Hong Kong investor, opened in 1994. With 552 rooms in its 14 storeys, it was the largest hotel in Vietnam and boasted quite possibly the first escalators in the city. The project was selffinanced, thus circumventing the ban on syndicated loans imposed by the US trade embargo. Three-quarters of the USD 62.5 million budget was contributed by the Hong Kong investor New World, with Saigontourist Holding Company covering the balance (Michael, 1993). 
By 2001, many of the large international hotel chains had opened hotels in Vietnam, with many of the hotels in the biggest cities being operated by Vietnamese/foreign joint ventures (VNAT/UNDP/WTO, 2001: 41). In 2000, 182 of the 194 foreign-invested hotel and tourism projects were joint ventures, with 6 each of 100 per cent foreign-funded projects and business cooperation contracts. As of 2006, a US investor plans to build a USD 1 billion five-star international standard resort and entertainment on Phu Quoc Island (Phu Quoc Island Snares 1 Billion USD Resort, 2006). In this same year, there were 190 FDI tourism projects in Vietnam with capital of USD 4.64 billion. The VinaLand Fund of the investment bank VinaCapital, acquired a 70 per cent stake in the Sofitel Metropole Hotel in 2005 and a 52.5 per cent stake in the Hilton Hanoi Opera in 2006, and is planning a further USD 43 million of investment in tourism projects in Hanoi and USD 3.1 million in a golf resort in Danang. The International Hotel Group, the world's largest accommodation operator, plans to open its first hotel in Vietnam in 2009 (John, 2006).

The Roles of Foreign and Domestic Partners in FDI / Joint Venture Hotel Projects

The infusion of money and knowledge into the Vietnamese tourism industry are obvious contributions by foreign partners in FDI ventures. The General Director of the Huong Giang Tourist Co., for example, has declared that co-operation with foreign companies helps local operators to improve on the quality of their services, thus raising their competitiveness (Vietnam News Agency, 2006). Aside from bringing the financing, know-how, experience and industry connections to joint-venture projects, foreign partners in joint-venture hotel projects have been active in encouraging the government to take a progressive stance on other facets of the tourism sector. For instance, according to a member of the European Chamber of Commerce, 
organizations such as the European Chamber of Commerce, the American Chamber of Commerce and the Hotel Association in Ho Chi Minh City were instrumental in persuading the government to lift visa requirements for Japanese tourists to encourage foreign investment by boosting traffic, and they have been working on similar initiatives for American and European visitors (Interview B, 2004).

Although unable to contribute much in the way of capital, Vietnamese partners in joint ventures contribute in other ways. All land is owned by the Vietnamese central government but can be leased, though buildings on the land may be privately owned. Vietnamese interests will often provide the land for joint venture projects. Sometimes government departments enter into joint ventures with foreign firms by making land under their control available for development. The Pullman Metropole Hotel in Hanoi was upgraded to four-star status by a French/Japanese joint venture in which the Vietnamese building contractor Jeals received a 20 per cent share in exchange for contributing construction labour and materials (EIU, 1993: 69-70). Domestic partners are also more familiar with navigating the Vietnamese and legal processes and more able to anticipate and adapt to the rapid changes that characterize transition-era Vietnam (Magnier, 1992).

An 'unwritten law' which gives the minority shareholder the same control and rights as the majority partner gives Vietnamese firms an added incentive to team up with foreign investors. The inequity of this provision is one of a number of difficulties met by foreign firms wishing to enter into joint ventures in Vietnam. Once the firm has surmounted the initial hurdle of finding an appropriate local partner, an agreement must be reached that satisfies not only the two 
partners, but also the government, which may demand substantial revisions before granting approval (Militante, 1993). Even when an agreement is reached with the national-level governmental bodies, there is no guarantee that the provincial authorities will let a project go ahead (Interview B, 2004).

Improvements in conditions for FDI in Vietnam Tourism

The adoption of the Vietnam-US Bilateral Trade Agreement, Vietnam's new membership in the ASEAN Free Trade Area and joining of the World Trade Organization were cited as reasons for instituting changes in conditions for FDI in Vietnam (Vietnam to Adopt Common Investment Law, 2003; Interview A, 2004), as was the general goal of achieving competitiveness through a free market, including the need to remain competitive with other developing countries like India and China (Interview A, 2004). Foreign operators of hotels in Vietnam interviewed by the lead author remarked on the increased ease of operation resulting from the relaxation of restrictions on banking and visa matters, and some investors who failed in earlier endeavours in Vietnam are now confident enough to return for a second try.

Foreign investors in Vietnam's accommodation sector have been making progress in their collaborations and communications with government and other operators in the tourism sector. The General Manager of an international hotel mentioned that the government organizes official conferences twice a year, at which government representatives meet with representatives of most of the foreign investment companies involved in joint ventures, to discuss and debate policy. These hotels also collaborate with local partners such as Vietnam Airlines and Saigontourist, to promote Vietnam as a destination (Interview C, 2004). However, a General Manager of a five 
star joint-venture hotel noted that government-organized meetings happen on a very ad hoc basis, with notifications and invitations to large events like a road show in Korea coming just two weeks before the actual event (Interview B, 2004).

\section{State-Owned Accommodation}

\section{Overview}

The majority of new hotels developed in Vietnam are state-owned, in many cases as part of joint ventures with foreign investors (VNAT/UNDP/WTO, 2001: 45). Most of these are owned by city and provincial tourism bodies, for whom they provide a major source of income, especially in the larger cities. (Travel Business Analyst, 1992: 13). It was estimated that 60 per cent of the one- to five-star grade hotels and 65 per cent of all hotel rooms in Vietnam in 2001 belonged to state owned enterprises (SOEs), owned by state bodies at levels from the national ministries down to the district or commune level. It has been argued that the predominance of state ownership of hotels results in a type of built-in government regulation in the accommodation industry (VNAT/UNDP/WTO, 2001: 109, 159), but the diversification of this control over so many levels and bodies of government can never be expected to achieve the homogenous policies possible with a centrally controlled market.

Ties to the cumbersome government bureaucracy can prove a handicap for state-owned hotels. One executive of a state-owned hotel mentioned that time-sensitive initiatives like publicity campaigns can be wrecked by the long wait for government approval of the campaign (Interview 
D, 2004). Interviewees gave mixed responses as to the degree of autonomy that the General Managers of state-owned hotels are granted. While one reported that he was free to make all dayto-day decisions in the running of his hotel without consulting a higher authority, another remarked that even the smallest of renovations cannot be authorized by the hotel manager without the funding and approval of the local government Labour Department. Although even managers themselves are not always sure in which cases they must ask permission and in which cases they are free to exercise their own discretion, in general any physical alteration to a building requires government approval. Several General Managers stated that government financial support for state-owned hotels for the most part has been withdrawn and each hotel must attract its own guests, organize its own financing and ensure its own profitability.

\section{Challenges posed by FDI / Joint venture hotels}

The recent proliferation of foreign joint venture hotels poses a challenge for existing non-jointventure state-owned hotels, which must now compete against hotels in quantity and quality that did not exist in their market before doi moi. In response, some hotels have established sales or marketing departments where previously a reservation department was deemed sufficient (Interview D, E, F, G, 2004). The first sales department in a state-owned hotel was set up by the Majestic Hotel in Ho Chi Minh City in 1995, in direct response to the stiff competition brought by the highly profitable joint-venture Floating Hotel and Omni Saigon Hotel. These hotels served as both the impetus and the model for progressive management thinking in the state-owned hotels that were their direct competitors. The Director of Sales and Marketing at a state-owned hotel freely admits to learning about pricing and promotion from the hotel's joint-venture rivals. Contrarily, a VNAT official denied that joint-venture hotels have had any effect on state-owned 
hotels perhaps indicative of the degree to which state-owned hotels have assumed their own autonomy and must solve their own problems, which may not even be acknowledged at the governmental level (Interview F, K, 2004).

Several General Managers of state-owned hotels acknowledged that with their global reach and experience and economies of scale, joint-venture hotels are able to offer bonuses such as discounts at their other hotels, and are more able to deal with international bookings and tracking-down of non-paying guests. Restricted in their scope to ventures inside of Vietnam, state-owned hotels cannot compete in these aspects.

Some state-owned hotels still rely heavily on government bodies to provide them with guests. The Sapa Trade Union Hotel in Sapa in the North of Vietnam, for instance, caters mainly to domestic tourists including, as its name implies, trade union tour groups (Interview H, 2004). Such arrangements provide dedicated distribution channels for marketing as well as a steady source of clients. However, most state-owned hotels must compete in the same market as foreign and domestic private enterprises for the same pool of customers. Because state ownership of hotels is most prevalent among Vietnam's star-rated hotels, this requires that they predominantly address the foreign tourist market and interviewees expressed the expansion of their foreign customer base as an important goal.

Having previously received guests primarily from Eastern bloc countries, state-owned hotels must adjust to the higher standards of service and facilities expected by the Western travellers who make up an increasing number of their customers since 1986. Many older urban hotels 
dropped their Vietnamese names and reverted to their Western-sounding pre-1975 names after doi moi (Travel Business Analyst, 1992: 26), apparently to appeal to the foreign market. The Dan Chu Hotel in Hanoi, for example, receives around 75 per cent foreign guests and 25 per cent domestic. The Deputy General Manager of a state owned hotel in Hanoi has said that the concept of guest-oriented thinking was unknown to the hotel management before 1993. Until that time, occupancy had been guaranteed by an undersupply of hotel rooms, and the government could be counted on to provide subsidies. With increasing competition and the slow withdrawal of government support, his hotel began to accept credit cards in 1995 and a policy of seasonal pricing was adopted for the first time in 1998 (Interview G, 2004). Executives at state-owned hotels have intimated that a lower room rate or special offers apply for Vietnamese guests, and that domestic tourists are targeted more aggressively during the low season for international tourism.

\section{Responses to challenges}

Low price was often mentioned by the interviewees as one distinct advantage that state-owned hotels still retain against the joint-venture competition, to offset their lower standards of facilities and service. This price differential is partly a function of lower operating budgets due to lower provision of facilities and service and the hiring of local staff rather than foreigners. State hotel managers interviewed have said that they would very much like to hire foreign staff for higher positions in their hotels, in order to bring in foreign experience and attract foreign business, but cost is a severe limitation. One manager has said that she would have to pay a foreigner USD 1,000 to 2,000 a month for a position in which a Vietnamese would earn USD 400 to 500 (Interview F, 2004). The management of two of the hotels at which interviews were conducted 
decided to hire a single foreigner in an attempt to attract more foreign trade. Interestingly, in both cases the foreigner hired was a food and beverage staff member: in one case a manager and in the other case a chef (Interview E, F, 2004).

The General Manager of a state-owned hotel said that foreign training manuals and videos are used to try to indoctrinate his staff in international standards of service. In 2004, the Rex Hotel received the environmental certificate ISO14001, for which it had been preparing for two years. Recognition of the importance of environmental issues to Western guests was a primary impetus behind this goal. In 2004, the Continental Hotel became the second hotel in Vietnam to receive the ISO 14001 environmental certificate (Continental Hotel Wins ISO 14001, 2005) and the Majestic Hotel has also started working towards this certification.

Long-established state-owned hotels are improving their facilities to keep up with the international market. Ho Chi Minh City’s 4-star Rex Hotel plans to open a new 70-room 5-star hotel, with a 1000-person conference hall, parking and pool. The hotel has been allocated a 3,000 square meter site by the municipal People’s Committee (a substantial benefit of running a stateowned hotel) and will be investing up to VND 300 billion (USD 19.4 million) building new facilities (Son Tran, 2003). Older inner-city state-run hotels may be frustrated in their ambitions to upgrade due to contextual constraints. The Continental Hotel in the centre of Ho Chi Minh City has no space to provide parking, a swimming pool or any other facilities. The hotel was built before automobiles and mopeds became ubiquitous on Saigon's streets. The large windows that served to ventilate the building now must be kept closed to keep out the traffic noise and pollution but guests still complain about the noise level. Some outmoded state-owned hotels, like 
the Hoan Kiem and Dan Chu hotels in Hanoi, are planned to be torn down and replaced with new four-to-five-star accommodation.

\section{Staffing and Service Reform}

Whereas before doi moi only communist party members or those with good government contacts were allowed to work in hotels in Vietnam, in part to isolate the general Vietnamese population from contact with foreigners, ordinary Vietnamese are now allowed to rent rooms directly to foreigners (Interview I, 2004). The state-owned hotels investigated by the first author through interviews often have a corps of long-term employees who have been in the hospitality industry, or even at the same hotel, for decades. The benefits of long-term staff loyalty notwithstanding, these staff members are disadvantaged in that they gained their training and much of their experience in a hotel industry that put little emphasis on customer-orientation or accommodating foreign guests. New staff members generally have formal education in tourism and hospitality from a vocational school and receive on-the-job training from the older staff (Interview F, 2004). Many hotels also give their staff foreign language training and other types of courses. This applies to all grades of staff from the highest to the lowest. However, as several interviewees noted, it is difficult for state-owned hotels to hold on to new staff because foreign-owned and joint-venture hotels are able to lure them away with higher salaries. The Deputy Manager of a state owned hotel in Hanoi noted that before doi moi, Saigontourism organized only one training course with the director of a big Ho Chi Minh City hotel every one or two years for the staff of the hotel where she was employed. Since Vietnamtourism Hanoi has entered a joint venture with Sofitel Metropol, employees of other Vietnamtourism Hanoi hotels are sometimes sent to the 
joint-venture hotel to train and to take advantage of the foreign expertise. Staff are also sent to Ho Chi Minh City to train because the hotel system in the South is still perceived as superior to that in the North (Interview G, 2004).

Some state hotels are expanding the services offered in-house to include amenities such as massage and travel services, rather than the rooms-only offering of pre-doi moi. It is common for small private operators to offer services and run businesses such as a dance club or gallery inside state-owned hotels, providing added income to the hotels through the rent they pay (Interview D, H, 2004).

\section{Outlook for the State-owned Sector}

The 'Revised National Tourism Plan for Vietnam 2001-2010, Draft Report' issued by the VNAT/UNDP/WTO endorses a continuation of dual private and public ownership, promoting a careful and considered approach to privatisation to allow for the establishment of requisite regulatory systems and bodies. However, the Draft Report also mentions a three- and five-year program for the reform of state-owned enterprises (SOEs) that included 'equitization' of state enterprises by sale of shares, sale or free transfer of some complete SOEs to private interests, liquidation of non-performing SOEs and restructuring of the remaining government enterprises to enhance their autonomy and accountability (VNAT/UNDP/WTO, 2001: 109, 159).

The state-owned accommodation sector began the post-doi moi period with a strategic advantage

over the private sector newcomers to the market by virtue of its possession of a number of established hotels in historic buildings in good locations in the urban centres of Vietnam. 
However, competition from foreign joint venture hotels has inspired state hotels to strive for improvements in profitability and standard of service and facilities. Many hotels have been renovated or newly built to keep up with the demand of the international market. The withdrawal of direct government support means that these accommodation providers must operate by different economic parameters than in pre-doi moi years, bringing about a change in their management culture and service attitude.

\section{Conclusions}

Political transition in Vietnam has affected developments in tourism and in the accommodation sector in particular in a number of ways. The rise in Vietnam's attractiveness both as a leisure and a business destination in recent years, and the resulting marked increase in tourism numbers, can be traced directly back to the declaration of the open door policy in 1986. Aside from the sheer rise in numbers, different types of tourists have begun to enter the country since this time. The small cohorts of political and industrial tourists from COMECON (Council for Mutual Economic Assistance) countries that came to Vietnam in the pre-doi moi years have been replaced by a much broader spectrum of travelers from a far greater number of countries. Table 1 below gives a summary of the developments discussed in this paper, within the context of political and economic events in Vietnam since the beginning of doi moi. 
political, economic events

foreign direct investment

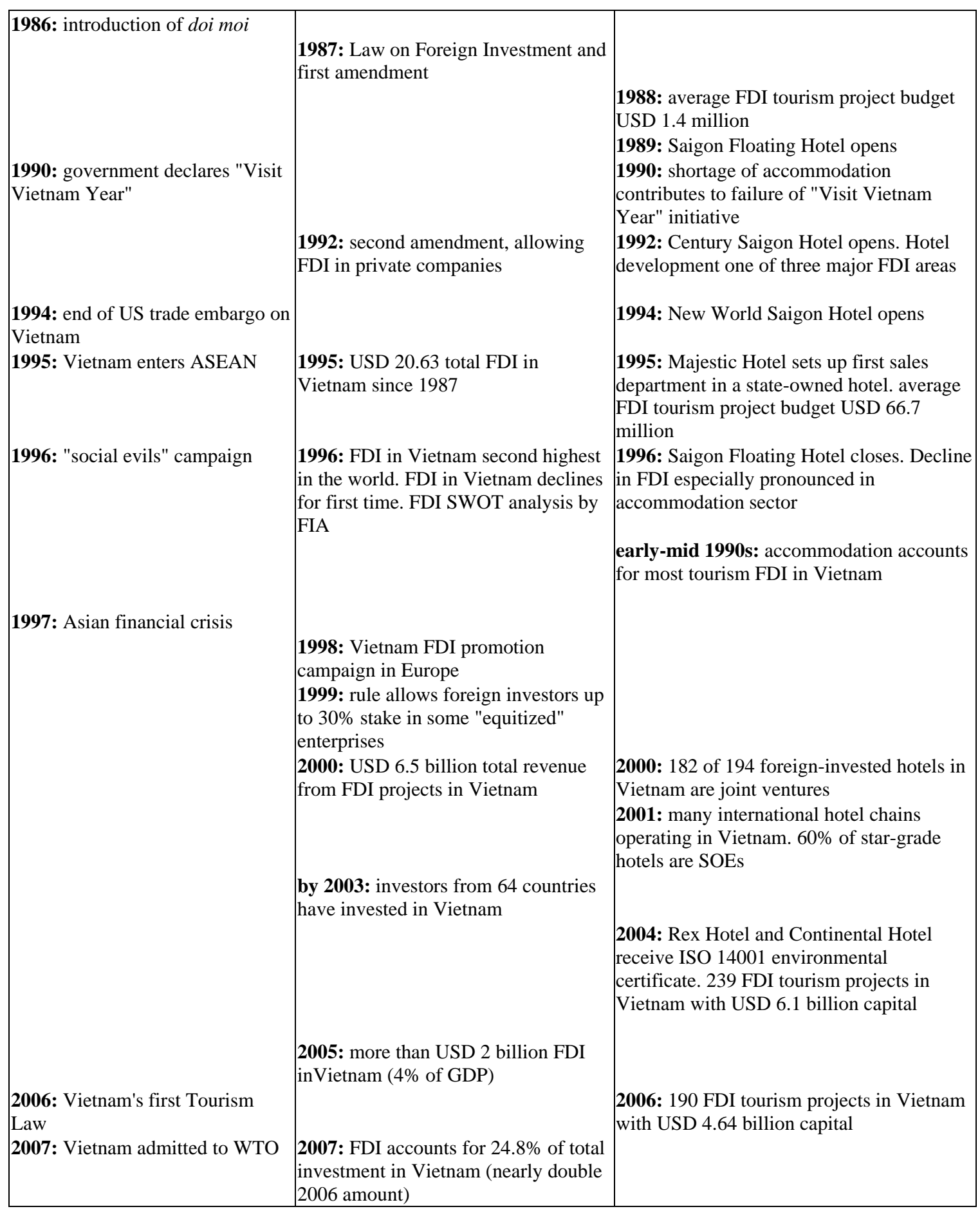

\section{Table 1}


Vietnam's new membership in ASEAN and its entry into the WTO are signs of the government's eagerness to enter into the global community of nations so long denied it. Reforms in investment law and other legislation, aimed at satisfying the requirements of entry into these organizations, affect accommodation businesses. The involvement of organizations like the UN, the WTO and the UNDP in Vietnam introduces a global perspective to tourism planning and has led to the drafting of the country’s first Tourism Law, which took effect in January 2006.

The accommodation sector in Vietnam has had a formative effect on political development in many ways during doi moi. Very early in the period after 1986, it became clear that the tourism provisions and infrastructure were qualitatively and quantitatively far below what was required to satisfy the new types of visitors. Lacking the expertise and finances to transform its tourism industry from within, the government resolved to relinquish its monopoly on tourism by courting foreign joint venture partners in order to encourage the growth of a free market within which state-owned firms competed alongside private sector businesses. Thus a desire to reap maximum benefits from tourism led to a compromise of a basic tenet of previous government policy. In return, foreign joint ventures have brought international standards to Vietnamese tourism and thereby given a new impetus for improvement to state businesses.

Because of FDI, hotels in Vietnam have improved qualitatively and increased quantitatively and in size. The incursion of large international hotel chains has inspired state-owned hotels to increase in size and improve in terms of service. New kinds of tourists have been arriving in 
conjunction with new provisions offered by hotels such as conference facilities. FDI has brought new management styles and marketing strategies to the accommodation sector in Vietnam.

FDI joint-venture newcomers to the accommodation sector in Vietnam have redefined the market parameters and have played a part in encouraging or necessitating reforms in the way stateowned enterprises (SOEs) operate. State accommodation has been forced to assume a more dynamic, customer-oriented stance by the competition brought by joint ventures. Reorganization, streamlining, equitization and privatisation of state enterprises are some of the results of efforts to remain competitive in the market. The opening of markets to foreign direct investment in addition to traditional state-owned enterprises has brought about competition, consolidation and differentiation in the accommodation sector that did not exist under the previous state monopoly. A higher grade of customer-responsiveness and more highly trained staff are now in demand to serve this more differentiated and discerning market, and Vietnam's accommodation market is now orienting itself to international standards. These processes in the accommodation industry are mirrored by similar transformations in other facets of tourism, and there are rich opportunities for further research into the ways in which the involvement of foreign interests, expertise and finances are affecting other tourism sub-sectors such as tour operators and National Parks. 


\section{References}

Abbott, J., and Abbott, S., 1996. International Arbitration as a Means of Resolving Disputes: Implications for Vietnam Tourism. Conference Proceedings: Tourism in Indochina: Opportunities for Investment, Development, and Marketing. Ho Chi Minh City, April 25-27, pp191-199.

Batha, E., 2000. Vietnam: A new Asian Tiger? BBC News. http://new.bbc.co.uk/2/hi/asiapacific/default.stm Accessed: 28 August 2002.

Biles A., et al., 1999. Romancing Vietnam: The Formation and Function of Tourist Images in Vietnam, in: Forshee, J., C. Fink and S. Cate. Berkeley (eds), Converging Interests: Trader, Travellers, and Tourists in South East Asia. University of California Press, California, pp207-233.

Continental Hotel Wins ISO 14001, Saigontourist Website, http://www.saigontourist.com/news/detail_en.asp?id=873 Accessed January 302005.

Country Inbound Profile Special Report on Vietnam, 1992. Travel Business Analyst, Hong Kong. 
Domestic Tourism Industry Feels Heat, 2006, November 15. Vietnam News Agency, http://www.vietnamnews.com.vn/showarticle.php?num=01TRA151106 Accessed 22 September 2006.

Dodsworth, J., et al.,1996. Vietnam: Transition to a Market Economy, International Monetary Fund, Washington.

Duiker, J. W., 1995. Vietnam: Revolution in Transition, second ed., Westview Press, Boulder.

EIU International Tourism Reports No 2, 1993. Indochina-Vietnam, Cambodia \& Laos, The Economist Intelligence Unite, pp59-82.

Endo, K., 2006. Foreign Direct Investment in Tourism—Flows and Volumes, Tourism Management (27), pp. 600-614.

Erramilli, M., Luu, T., Gilbert, L. and Hooi, D., 1997. Foreign Direct Investment Patterns in the Vietnamese Tourism Sector, Conference Proceeding for International Conference on Sustainable Tourism Development Hue, pp 276-310.

Foreigners Can Buy Stakes in Equitized Stated Companies, 1999. The Saigon Times Daily, June 30. 
Freeman, N., 2002. Foreign Direct Investment in Vietnam: An Overview, paper prepared for the DfID Workshop on Globalisation and Poverty in Vietnam, Hanoi, 23-24 September 2002.

General Statistics Office of Vietnam. http://www.gso.gov.vn/default_en.aspx?tabid=471 \&idmid=3 Accessed 28 August 2008.

Henderson, J., 2000. War as a Tourist Attraction: The Case of Vietnam, International Journal of Tourism Research (2), pp. 269-280.

Hines, T., 2000. Will Vietnam Roar Again? BBC News. http://news.bbc.co.uk/1/hi/business/ 1026551.stm Accessed 28 August 2002.

Ho Chi Minh City, 1990. Guide Book for Foreign Tourists and Business People, Saigon Tourist and Saigon Tourist Association, Saigon.

Investment Projects Lined Up on Phu Quoc Island, 2008. http://www.vietnamtourism.gov/vn Accessed 5 September 2008.

John, K., 2006. Vietnam Opens wide to tourism, Asia Times Online. http://www.atimes.com /atimes/Southeast_Asia/HJ12Ae02.html Accessed 18 January 2007. 
Kokko, A., 1998. Vietnam-Ready for Doi Moi II?, Stockholm School of Economics: SSE/EFI Working Paper Series in Economics and Finance No. 286. http://swopec.hhs.se/hastef/abs/hastef0286.htm Accessed February 202003.

Law on Foreign Investment in Vietnam, 1987. Amended 30 June 1990 and 23 December 1992.

Li, L., Lee, P., and Tan, A., 1998. Indochina-Emerging Markets for the Tourism Industry, Journal of the International Academy of Hospitality Research, Issue 12. http://scholar.lib.vt.edu/ejournals/JIAHR/issue12/ Accessed 10 January 2007.

Leproux, V., and Brooks, D., 2004. Viet Nam: Foreign Direct Investment and Postcrisis Regional Integration, ERD Working Paper Series No. 56. Economics and Research Department, Asian Development Bank.

Le Van Sang, 1995. The Role of Foreign Direct Investment in Vietnam's Economic Development, in Vietnam Marketing 1995-1996, HCMC, pp111-158.

Lloyd, K., 2004. Tourism and Transitional Geographies: Mismatched Expectation of Tourism Investment in Vietnam. Asia Pacific Viewpoint, vol. 45 (2), pp. 197-215. 
Lloyd, K., et al., 2004. Changing Research Spaces: Doing Human Geography Fieldwork in Vietnam, Paper presented at Biennal Conferences of the Asian Studies Association of Australia, Canberra.

Magnier, M., 1992. First come, First served, Asia Travel Trade.

Michael, B., 1993. New World Thinks Big in Vietnam, South China Morning Post, May 12.

Militante, G., 1993. The Dawning of a Century, Asia Travel Trade, October.

Mitton, R., 1998. Doi Moi Part 2?: Crisis Jump-Started Reforms in 1986. It May Do the Same Again Today, http://www.nufronlive.org/vinsight/1998 news/0423.htm Accessed 7 August 2002.

Mok, C., and Lam, T., 1996. Hotel and Tourism Development in Vietnam, An Overview of Its Potential and Constraints. Conference Proceeding for Tourism in Indo-China: Opportunities for Investment, Development and Marketing, HCMC: University of Houston and University of d'Angers, pp. 23-40.

Ngo Ba Thanh, 1993. The 1992 Constitution and the Rule of Law, in Thayer, C., and Marr. D. (eds), Vietnam and the Rule of Law, The Australian National University, Canberra, pp 81115. 
Phu Quoc Island Snares 1 Billion USD Resort, 2006. http://www.vietnamtourism.gov.vn/ Accessed 20 November 2006.

Phu Quoc Lures \$1.72 Billion in Investment, 2008. VietNam NetBridge http://english.vietnamnet.vn/biz/2008/08/800352/ Accessed 2 September 2008.

Revised National Tourism Development Plan for Vietnam 2001-2010: Draft Report, 2001. VNAT/UNDP/WTO.

Sadi, M., and Henderson, J., 2001. Tourism and Foreign direct investment in Vietnam, International Journal of Hospitality \&Tourism Administration, 2 (1), pp 67-90.

Son Tran, 2003. Rex Hotel to Get Five-Star Facelift, Vietnam Investment Review, March 17. Tenev, S., et al., 2003. Informality and the Playing Field in Vietnam’s Business Sector. IFC, World Bank and MPDF. Washington D.C.

Thayer, C., 2000. Vietnam, the Asian Financial Crisis and Doi Moi 2, Harvard Asia Quarterly, IV(1) http://www.fas.havard.edu/ asiactr/ haq/200001/00 01a003.htm Accessed 20 September 2002.

The Mekong Region: Foreign Direct Investment, 2006. ADB.

The Saigon Floating Hotel, http://www.kurtwalter.net/the-saigon-floating-hotel.htm Accessed 15 January 2005. 
Theuns H., 1997. Vietnam: Tourism in an Economy in Transition, in Frank, M. Go. and Jenkins, C. (eds), Tourism and Economic Development in Asia and Australia, Cassell, London, pp304-318.

Tourism Development Master Plan, 1991, 1991. Socialist Republic of Vietnam. Summary Report. United Nations Development/WTO.

Tourism Statistics, VNAT Website. http://www.vietnamtourism.com/index/e_index.asp Accessed August 122006.

Vasavakul, T., 1997. Vietnam: The Third Wave of State Building, Southeast Asian Affairs, pp. 331-363.

Vietnam to adopt Common Investment Law, 2003. VietNamNet, December 26.

Vietnam to Develop Tourism Sector, 2004. Vietnam News Agency http://www.vnagency. com.vn/pPrint.aspx?itemid=88674 Accessed 20 November 2006.

Wayne, L., and Lejeune, L., 1996. Investing in Hotels and Tourism in Vietnam, Conference Proceeding: Tourism in Indochina: Opportunities for Investment, Development, and Marketing, Ho Chi Minh City, April 25-27, pp 200-210. 
Why Invest in Phu Quoc, Vietnam? http://investphuquoc.com/investment.html Accessed 4 September 2008.

World Maritime News, 1997. http://www.transport.ru/2_period/wmn/97/11_04_97.htm Accessed 3 February 2007. 